\title{
THE ART OF CITIZENSHIP
}

\section{Roman Cultural Identity in Cicero's Pro Archia Poeta}

THIS PAPER EXAMINES CICERO'S PRO ARCHIA POETA ORATIO AND THE AUTHOR'S IMPLICIT AND EXPLICIT VIEWS ON HOW ROMAN CULTURAL IDENTITY IS CONSTRUCTED. WHILE THE SPEECH ITSELF IS THE LEGAL DEFENSE OF THE POET ARCHIAS' CLAIM TO ROMAN CITIZENSHIP, IT ALSO SITUATES THE DEBATE OF LEGAL CITIZENSHIP WITHIN A BROADER CONTEXT OF ROMAN CULTURAL IDENTITY. MORE SPECIFICALLY, IT IS ARGUED THAT THE ORATION ALLOWS CICERO TO EMPHASIZE THE COMBINATION OF ARTES, IN THIS CONTEXT REPLACING THE LITERAL DEFINITION OF "SKILL" OR “ART" WITH A FOUNDATIONAL AND NECESSARY ROMAN VIRTUE, AND HUMANITAS AS A MEANS OF DESCRIBING THE ROLE EDUCATION PLAYS IN CREATING ROMAN IDENTITY. FOR CICERO, THE COMBINATION OF ARTES AND HUMANITAS RESULTS IN A TYPE OF EDUCATION ORIENTED TOWARD CHARACTERISTIC ROMAN VIRTUES LIKE HONOR, GLORY AND PUBLIC SERVICE, WHICH SERVES AS THE BASIS FOR HIS DEFINITION OF ROMAN CULTURAL IDENTITY. THIS ARGUMENT COMES PRIMARILY FROM THE DECONSTRUCTION OF THE ORATION AND THE EXAMINATION OF SPECIFIC PASSAGES TO IDENTIFY KEY THEMES AND EXPRESSIONS, AND COMBINING THIS ANALYSIS WITH RECENT ACADEMIC SCHOLARSHIP ON CICERO'S ORATIONS. 
Cicero's famous defense of the poet Aulus Licinius Archias in Pro Archia Poeta Oratio remains one of the most eloquent and important works of Latin literature to date. The work celebrates the merits of literature and art, which offers a powerful description of what makes an individual Roman. At its most basic, the speech itself constitutes the verbal arguments supporting Archias' claim to Roman citizenship. More broadly, the speech articulates Cicero's model of Roman citizenship and cultural identity. Historian Vassiliki Panoussi defines culture as a conglomeration of protocols, behavioral patterns, microsocial expectations, and ideological formations." In the Pro Archia, Cicero shares his own views of these cultural foundations for Romans. ${ }^{2}$ This paper argues that Cicero's oration combines artes into a broader definition of humanitas, which defines the role of education in creating a Roman identity. This combination of artes and humanitas results in education oriented toward the public service, and one which maintains the virtues of glory and honor in the face of sacrifice and personal loss.

The Pro Archia Poeta is a unique example of Cicero's orations at the height of his political and social success. In the year $6_{3}$ B.C., Cicero had secured the position of Consul, the highest honor in Rome, and the title of novus homo, which represented the ultimate political success and ascent in the Roman Republic. He had also successfully thwarted the Catiline conspiracy by driving the tyrant from Rome. It was in the wake of these victories, with Cicero as former Consul and savior of the Republic, that the great orator defended his close friend Archias. Historian Harold Gotoff argues that Cicero embraces an unusual literary forensic style in the Pro Archia, as he writes, "the Pro Archia is undoubtedly the least typical speech of the Ciceronian corpus." 3 He continues, "Perhaps Cicero's

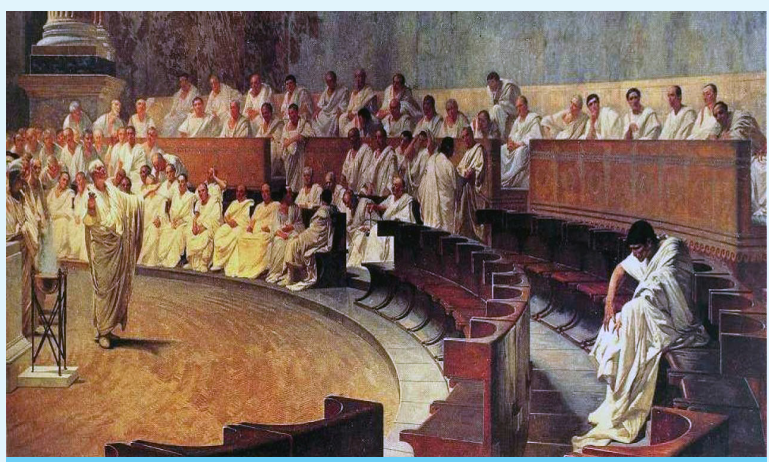

A PAINTING DEPICTING CICERO'S DEFENSE OF ARCHIAS (COURTESY OF WIKIMEDIA COMMONS) judgment and tact convinced him that the only way to present his argument, weak on evidence, was to evoke the elegant and decorative aspects of human letters in defense of a poet." 4 However, John Dugan contends that this unusual style creates the foundation on which Cicero defends his client and shapes the speech to fit his overall description of Roman identity. Dugan writes:

By transforming the Pro Archia into an epideictic oration whose praise of poets and poetry defended Archias' claim to Roman citizenship, Cicero allows himself to subordinate the legal case to the cultural arguments that are the essence of his oration. ${ }^{5}$

The opening of the Pro Archia Poetia signals an important shift from a forensic speech to a poetic and linguistically inspired oration. This establishes a better platform for Cicero's definition of Roman citizenship and cultural identity to expand beyond the legal definition of both. Cicero opens the Pro Archia by asking for the indulgence of the audience, the jury, and the praetor for the less traditional manner of speech used in his defense of Archias. Cicero says at the opening of the oration:

Sed ne cui vestrum mirum esse videatur me in quaestione legitima et in iudicio publico, cum res agatur apud praetorem populi Romani, lectissimum virum, et apud severissimos iudices, tanto conventu hominum ac frequentia, hoc uti genere dicendi, quod non modo a consuetudine iudiciorum, verum etiam a forensi sermone abhorreat, quaeso a vobis, ut in hac causa mihi detis hanc veniam, accommodatam huic reo, vobis, quem ad modum spero, non molestam, ut me pro summo poëta atque eruditissimo homine dicentem, hoc concursu hominum litteratissimorum, hac vestra humanitate, hoc denique praetore exercente iudicium patiamini de studiis humanitatis ac litterarum paullo loqui liberius et in eius modi persona, quae propter otium ac studium minime in iudiciis periculisque tractata est, uti prope novo quodam et inusitato genere dicendi.

It may, however, be a matter for surprise in some quarters that in an inquiry dealing with statute law, in a public trial held before a specially selected praetor of the Roman people and a jury of high dignity, in the presence of a crowded audience of citizens, my speech should be made in a style out of keeping not merely with the conventions of the bar, but also with forensic language. But I crave your indulgence, an indulgence which will, I trust, cause you no inconvenience, and which is 


\section{"[Cicero] concludes that intellectual activities, such as the 'enlightened and culitvated pursuits' of literature and poetry, are fundamental to one's Roman cultural identity."}

peculiarly applicable to the nature of my client's case; and I would ask you to allow me, speaking as I am on behalf of a distinguished poet and a consummate scholar, before a cultivated audience, an enlightened jury, and the praetor whom we see occupying the tribunal, to enlarge somewhat upon enlightened and cultivated pursuits, and to employ what is perhaps a novel and unconventional line of defense to suit the character of one whose studious seclusion has made him a stranger to the anxious perils of the courts. ${ }^{6}$

In the above passage, Cicero elevates the audience and jury to a place of high culture and learnedness. He describes them as "cultivated" and "enlightened," suggesting that he considers these qualities most important toward defining Roman cultural identity.

Further, Cicero uses this flattering and elevating language to transform the traditional legal style to suit his client Archias and to suggest the major themes of his defense of the poet. Historian Erika Nesholm suggests that the celebration of literature becomes the focal point of Cicero's speech. She writes:

The 'most serious jurors' (severissimos iudices) have now become an 'assembly of most learned men, this cultured jury' (hoc concursu hominum litteratissimorum, hac vertra humanitate); the trial has become an occasion for Cicero to speak about cultural and literary pursuits (de studiis humanitatis ac litterarum paulo loqui liberius).?

These themes noted by Nesholm constitute Cicero's interpretation of what makes a man culturally and socially Roman. He concludes that intellectual activities such as the "enlightened and cultivated pursuits" of literature and poetry, are fundamental to one's Roman cultural identity. ${ }^{8}$

In the beginning of the oration, Cicero focuses on cultural and literary pursuits to broaden Roman cultural identity and emphasizes the bonds between the artes and humanitas. He writes:

Etenim omnes artes quae ad humanitatem pertinent habent quoddam commune vinculum et quasi cognatione quadam inter se continentur.

Indeed, all the arts which pertain to a civilized society have a certain common bond, and by a certain, as it were, kindred relationship are connected to one another. ${ }^{9}$

This line suggests both the importance that the artes plays in humanitas, or civilized society, and the symbiotic relationship that arts and civilization have with one another. The two formerly dissimilar concepts - artes and humanitas - are linked by a special bond that both normalizes the relationship between the two concepts and connects the members of the trial (Cicero, Archias, the jury, and the praetor) in celebration of this bond. ${ }^{\text {ro }}$ Vassiliki Panoussi writes that:

the conceptualization of artes as a network of reciprocal relations establishes their relevance to and significance for society as a whole and thus grounds them implicitly - if not explicitly - within different facets of Roman life: social, political, military. ${ }^{\text {II }}$

Panoussi suggests that Cicero positions the artes within a broader context of Roman cultural identity and life and highlights the benefits derived from the study of artes, which include history, literature, and philosophy. The connection of literature and poetry with humanitas is a fundamental part of Cicero's understanding of cultural identity: a strong bond between the artes, like philosophy, literature, and poetry, and humanitas, informs the very fabric of Roman virtues and identity.

After establishing the more straightforward facts in defense of Archias' citizenship, Cicero suggests that the 
9 artes are important in the development of moral and virtuous people. ${ }^{\mathrm{I2}} \mathrm{He}$ says:

Sed pleni sunt onmes libri, plenae sapientium voces, plena exemplorum vetustas: quae iacerent in tenebris omnia, nisi litterarum lumen accederet.

All literature, all philosophy, all history, abounds with incentives for noble action, incentives which would be buried in black darkness were the light of the written word not flashed upon them. ${ }^{13}$

This passage demonstrates that from the artes, civilized men can learn about noble action, which would otherwise be lost to the world. Cicero suggests that without the writer, historian, or poet, light could not be shed on history and the foundation it provides to inform future, moralized action. In this way, Cicero combines the artes with humanitas to support one another, and to prescribe a historically-rooted social, political, and military conception of Roman cultural identity. Panoussi writes, "art and literature play a pivotal role in making Roman men, by instilling in them the venerable and time-honored Roman ideals, which in turn make them better able to serve the state." I4 The necessity of civic service is a central part of Cicero's definition of Roman cultural identity. Furthermore, in the above passage Cicero uses what Nesholm terms "metaphors of artistic production" to "firmly situate literature in a familiar Roman social and political context." ${ }^{15}$ Cicero's aim, as Nesholm suggests, is to position literature in the "place of ancestors in providing a distinguished background and establishing one's social and political standing." ${ }^{\prime 6}$ The artful metaphor used by

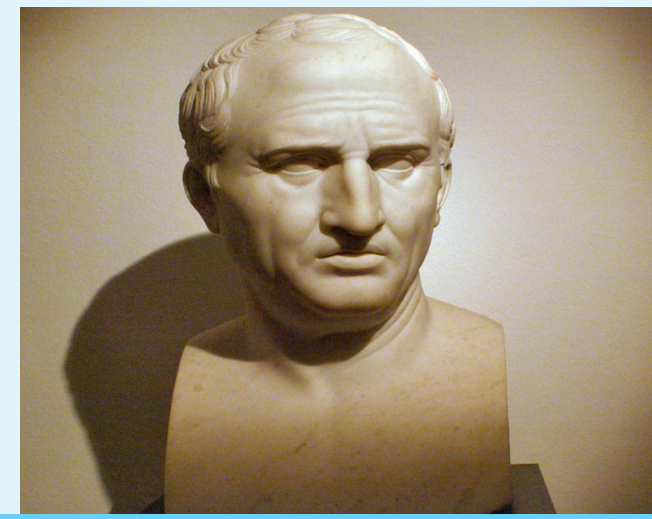

A MARBLE BUST OF CICERO (COURTESY OF WIKIMEDIA COMMONS)
Cicero has three aims. He first establishes the role of the poet, in this case Archias, as essential to the greatness of ancestral achievements and glory. Then Cicero places himself in the political crossroads of literature, political achievement, and legacy by supporting both the artes through Archias and by incorporating artes into the humanitas context of the trial. Finally, he depicts Roman cultural identity as both socially and politically grounded in the arts.

The practical role of grounding society in artes is more fully explained in the following lines of the above passage. Here, Cicero establishes the importance of literature and poetry with a detailed description of the moral benefits derived from such study, and he uses himself as the prime example of a Roman citizen who has practiced this method. He says:

Nam nisi multorum praeceptis multisque litteris mihi ab adolescentia suasissem nihil esse in vita magno opere expetendum nisi laudem atque honestatem, in ea autem persequenda omnes cruciatus corporis, omnia pericula mortis atque exsilii parvi esse ducenda, numquam me pro salute vestra in tot ac tantas dimicationes atque in hos profligatorum hominum cotidianos impetus obiecissem.

Had I not persuaded myself from my youth up, thanks to the moral lessons derived from a wide reading, that nothing is to be greatly sought after in this life save glory and honor, and that in their quest all bodily pains and all dangers of death or exile should be lightly accounted, I should never have borne for the safety of you all the brunt of many a bitter encounter, or bared my breast to the daily onsets of abandoned persons. ${ }^{17}$

Cicero again praises the use of literature in humanitas, which include the "moral lessons derived from a wide reading" (preaceptis multisque litteris). ${ }^{18}$ Cicero teaches that nothing is greater in life than "glory and honor" (laudem atque honestatem), and that attention to these virtues ought to come before "bodily pains," the "dangers of death," or even shameful "exile." I9 It is interesting too that Cicero begins to use himself as an example of these Roman virtues, which suggests that as a result of his intense study of philosophy, history, and literature, he has braved many dangers in the name of honor and glory. He also does this daily, suggesting the importance of striving continuously towards these virtues. 


\section{"Cicero uses himself as an example of just how the artes combine with the humanitas to educate the individual, present a clear, ethical model, and direct action aimed at some public career."}

Acting in this manner alone, however, is not enough; according to Cicero, some level of public work and engagement is also necessary. Cicero describes the central role that civic engagement plays in creating an ideal Roman man though his own career as an orator and statesmen, which relates his political success prior to giving the Pro Archia. He writes:

Quam multas nobis imagines non solum ad intuendum, verum etiam ad imitandum fortissimorum virorum expressas scriptores et Graeci et Latini reliquerunt, quas ego mihi semper in administranda re publica proponens animum et mentem meam ipsa cogitatione hominum excellentium conformabam.

How many pictures of high endeavor the great authors of Greece and Rome have drawn for our use, and bequeathed to us, not only for our contemplation, but for our emulation! These I have held ever before my vision throughout my public career, and have guided the workings of my brain and my soul by meditating upon patterns of excellence. ${ }^{20}$

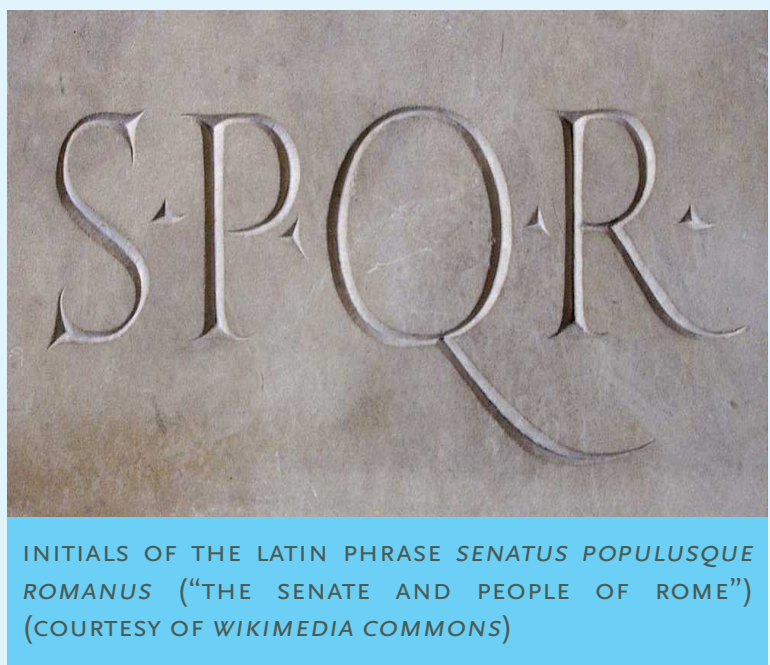

In the above passage on history, literature, and poetry, Cicero stresses that the "great authors" of Greece and Rome have provided "pictures of high endeavors" not just for contemplation, but more importantly for emulation. ${ }^{21}$ Further, this emulation of great acts must also be accompanied by proper engagement within a social and political context. In the wake of his consulship, and with the status of novus homo, Cicero exemplifies how literature, history, and poetry provides prime examples for leadership. These examples suggest not only that Cicero has incorporated the teachings from ancient texts into his actions, but also that these actions have been directed towards the public good. ${ }^{22}$ Further, these lofty values and moral teachings have guided Cicero's "brain and [...] soul by meditating on patterns of excellence." ${ }^{23}$ The takeaway from this passage is that a Roman is well learned and uses this education and morality for the public good. Cicero uses himself as an example of just how the artes combine with the humanitas to educate the individual, present a clear, ethical model, and direct action aimed at some public career.

The combination of the above analysis suggests a fairly clear interpretation of how Cicero viewed Roman cultural identity. We have already seen that Cicero firmly believes the artes and humanitas are not only related, but share a unique bond that informs the role of citizen in a special way. This bond creates a bridge between the artes of Greece and Rome, and the modern scholar, who reads and thinks about these influential works to cultivate a moral understanding of the world. More specifically, Cicero highlights the virtues of honor and glory that a Roman can learn from these artes, which are now a part of humanitas, and drives a man toward certain goals, even in the face of adversity. Finally, it is the daily and lifelong pursuit of these noble virtues through a broader education, combined with public works or office, which makes someone truly Roman. An important caveat involves what kind of person Cicero ultimately considers to be worthy, or even capable, of embodying Roman status. Cicero seems to apply a certain type of classism in deciding who can be considered 
i

culturally Roman, which is surprising given his own humble origins. Panoussi suggests that Cicero delineates between high and low forms of art, contrasting the work of Archias and a stage-actor Roscius, to highlight that humanitas "applies only to a select few" who appreciate high art and can derive lessons from poetry and literature. ${ }^{24}$ While this does not necessarily detract from his overall discussion on what makes someone culturally Roman, one must consider the type of person Cicero believed capable of being Roman.

It is a loss to contemporary readers that the outcome of this trial remains unknown. However, what is not lost on readers of this fascinating and unique text is Cicero's understanding of what makes a person in the ancient world culturally Roman. Further, this text helps situate the petty politics and legal debates that surrounded the question of authentic Roman identity, which appeared during the Roman Republic and afterwards. This text remains relevant today for just these reasons, and helps one answer questions regarding one's own cultural identity. Cicero makes a clear claim about his characterization of a Roman, which is beneficial to historians and casual readers alike in understanding how and why some people were Roman in a cultural, rather than in a strictly legal sense. And without reaching too far, one can see the application of Cicero's oration and our analysis of this text in the modern world. People too are steeped in political infighting and petty debate regarding how some people are culturally American, and why others are excluded. Perhaps a reading of Cicero can help shed light on their own problems. More likely, though, this masterful oration offers something more important to the modern reader: it allows him or her to bridge the debates and issues that occurred some two-and-a-half millennia ago to those of today in order to see the similar problems each society faced, and how they addressed these problems. As the adage goes, "Those who fail to learn from history are doomed to repeat it."

\section{ENDNOTES}

I. "Vassiliki Panoussi, "Roman Cultural Identity in Cicero's Pro Archia," Antiphilesis: Studies on Classical, Byzantine and Modern

Greek Literature and Culture (2009): $5 \mathrm{I} 6$.

2. Ibid. 516 .

3. Harold Gotoff, Cicero's Elegant Style: An Analysis of the 'Pro Archia,' (Urbana: University of Illinois Press, I979): 8I.

4. Ibid. 8I.

5. John Dugan, "How to Make (and Break) a Cicero: Expideixis, Textuality, and Self-fashioning in the Pro Archia and In Pisonem," Classical Antiquity 20 (200I): 44

6. Cicero, Pro Archia Poeta, 3.

7. Erika Nesholm, "Language and Artistry in Cicero's 'Pro

Archia,"” The Classical World II3 (2010): 48I.

8. Cicero, Pro Archia Poeta, trans. N.H.Watts, 8-9.

9. Cicero, Pro Archia Poeta, 2.

Io. Nesholm, "Language and Artistry in Cicero's 'Pro Archia,", 482.

II. Panoussi, "Roman Cultural Identity in Cicero's Pro Archia," 517.

I2. Cicero cites a number of factual reasons for why Archias should be considered a citizen before returning to the more literary forensic portion of the speech. Some of these more straightforward and factual reasons include: Archias had spent a great deal of time living in Rome as a citizen before the trial took place; Archias has been in the graces of the Lucilli; Archias had been entered as a full citizen of Heraclea, a town which had full civic privileges given its treaty with Rome; and because Archias had complied with all the regulations necessary to be considered a citizen of Rome.

I3. Cicero, Pro Archia Poeta, I4.

I4. Panoussi, "Roman Cultural Identity in Cicero's Pro Archia," 519 .

I5. Nesholm, "Language and Artistry in Cicero's 'Pro Archia,'” 483.

I6. Ibid. 484.

I7. Cicero, Pro Archia Poeta, I4.

I8. Cicero, Pro Archia Poeta, trans. N.H.Watts, 20-2I.

I9. Ibid. 20-23.

20. Cicero, Pro Archia Poeta, I4.

2I. Cicero, Pro Archia Poeta, trans. N.H.Watts, 22-23.

22. Ibid. 22-23.

23. Ibid. 22-23.

24. Panoussi, "Roman Cultural Identity in Cicero's Pro Archia," 520-52I. 
REFERENCES

Arno, Claudia I. “How Romans Became 'Roman': Creating Identity in an Expanding World.” PhD diss., University of Michigan, 20I2.

Cerutti, Steven M. and Cicero, Marcus Tullius. Cicero: Pro Archil Poet Oration: A Structural Analysis of the Speech and Companion to the Commentary. Wauconda: Bolchazy-Carducci Publishers, I999.

Cicero. Pro Archil. Post Reditum in Senatu. Post Reditum ad Quirites. De Dome Sra. De Haruspicum Responsis. Pro Plancion. Translated by N. H. Watts. Loeb Classical Library 158 . Cambridge, MA: Harvard University Press, I923.

Dugan, John. "How to Make (and Break) a Cicero: Expideixis, Textuality, and Self-fashioning in the Pro Archil and In Pisonem." Classical Antiquity 20 (200I): 35-77. Accessed April 5, 20I7. doi:IO.I525/ca.200I.20.I.35.

Goof, Harold. Cicero's Elegant Style: An Analysis of the 'Pro Archil.' Urbana: University of Illinois Press, I979.

Nesholm, Erika. "Language and Artistry in Cicero's 'Pro Archil." The Classical World II3 (2010): 477-90. Accessed March 2I, 20I7. doi:I0.1353/clw.2010.0002

Panoussi, Vassiliki. "Roman Cultural Identity in Cicero's Pro Archil." In Antiphilesis: Studies on Classical, Byzantine and Modern Greek Literature and Culture, edited by Elemi Karamalengou and Eugenia Makrygianni, 516-23. Statgat: Steiner, 2009 .

THE ART OF CITIZENSHIP 